\title{
PRELIMINARY RESULTS ON INTERSEXUAL DIFFERENCES IN GENE EXPRESSION OF CHEMOKINE K203 IN MONONUCLEAR CELLS OF CHICKEN
}

\author{
Zuzana KAŇKOVÁ ${ }^{1 *}$, Michal ZEMAN ${ }^{1,2}$, Susanne SCHWARZ ${ }^{3}$ and Bernd KASPERS ${ }^{3}$ \\ ${ }^{1}$ Department of Animal Physiology and Ethology, Faculty of Natural Sciences, \\ Comenius University Bratislava, Mlynská dolina, 84215 Bratislava 4, Slovak Republic; \\ ${ }^{2}$ Institute of Animal Biochemistry and Genetics, Slovak Academy of Sciences, \\ Ivanka pri Dunaji, Slovak Republic; ${ }^{3}$ Department of Veterinary Sciences, \\ Institute for Animal Physiology, Ludwig-Maximilians-University, Munich, Germany
}

(Received 1 April 2015; accepted 28 October 2015)

Sex steroid levels increase during sexual maturation and cause alterations in many physiological and morphological traits. Some of these changes may be connected with age-dependent and intersexual differences in the immune system. This topic is still insufficiently understood, especially in avian species, partially due to methodological limitations. In this study we measured the gene expression of proinflammatory cytokines (IL-1 $\beta$, IL-6, IL-18) and chemokines [K60 (IL-8-like chicken chemokine - CXCLi1), CAF (IL-8-like chicken chemokine - CXCLi2), and K203] in mononuclear cells isolated from blood and spleen after in vitro stimulation with lipopolysaccharide (LPS). Samples were collected from chickens at two ages (from pullets before sexual maturity and from sexually mature egglaying hens). After LPS stimulation, a substantial increase was recorded in the gene expression of IL- 6 and K203. All other measured genes were expressed at low levels in mononuclear cells irrespective of cell sources. We found a trend toward intersexual differences in K203 expression, but the expression of other cytokines and chemokines did not differ between the two sexes. The effect of stimulation was more pronounced in monocytes than in spleen macrophages, mainly in IL-6, IL-1 $\beta$ and K203 gene expression. Our findings represent a basis for further studies on the effects exerted by sexual hormones on the immune phenotype of birds. saccharide

Key words: Sex steroid hormones, chemokines, macrophages, lipopoly-

Gonadal steroids play an important role in shaping secondary sexual characteristics and may influence the formation of sexual dimorphism in the immune response. Females usually produce higher levels of circulating immunoglobulins than males (Beagley and Gockel, 2003): they display a more pronounced inflammatory response (Gilliver, 2010), and exhibit a higher incidence of autoimmune diseases than males as shown in mice and humans (Whitacre, 2001).

*Corresponding author; E-mail: kankova@fns.uniba.sk; Phone: 00421 (02) 60296-576 
The mechanisms mediating the effects of sex hormones on the immune system are largely unidentified. Studies in mammals indicate that gonadal steroids may modulate the activity of the immune system, among other effects by influencing the proliferation and activity of lymphocytes (Landsman et al., 2001; De León-Nava et al., 2009). Since macrophages possess receptors for gonadal steroids (Wunderlich et al., 2002; Khan et al., 2005; Murphy et al., 2009), another possible mechanism might be the alteration of cytokine and chemokine production. Production of cytokines may be modulated by the administration of substances stimulating the immune system, such as lipopolysaccharide (Leshchinsky and Klasing, 2003), which enables more detailed studies also at the level of gene expression.

Most conclusions on intersexual differences in immune system activity are derived from mammals, and data from avian species are insufficient. This gap results partially from the methodological limitations of immunological research in birds. The sequencing of genes for chicken cytokines and chemokines has provided a further tool for the evaluation of immunity in avian models. Gene expression of a wide variety of these inflammatory mediators was measured under basal conditions (Swaggerty et al., 2008) as well as after stimulation by pathogens in order to evaluate innate and adaptive immunity (Wigley et al., 2006; Kogut et al., 2013). In the present experiment, we validated quantitative PCR procedures for the evaluation of sex- and age-specific effects on gene expression of selected proinflammatory cytokines and inflammatory chemokines in phagocytic mononuclear cells isolated from the blood or spleen tissue of domestic chickens.

\section{Materials and methods}

\section{Animals and housing}

Non-SPF, female and male White Leghorn chickens of the M11 line $\left(\mathrm{B}^{\mathrm{x} 2 \mathrm{x}} / \mathrm{B}^{\mathrm{x} 2 \mathrm{x}}\right)$, derived from the Institute for Animal Science, Mariensee, Germany (Hartmann, 1988), were used in this study. Chickens were kept under standard conditions at the Department of Animal Physiology, Veterinary Faculty, Ludwig-Maximilians-University (LMU) Munich. The birds received feed and water ad libitum in all experiments. Samples were collected at two ages, from young pullets and cockerels before sexual maturity (7-11 weeks of age; females: $\mathrm{n}=4$; males: $\mathrm{n}=3$ ), and adult, sexually mature egg-laying hens and mature cocks (28-29 weeks of age; females: $\mathrm{n}=3$; males: $\mathrm{n}=3$ ). Blood collection was authorised by the Regierung von Oberbayern (Az. 55.2-1-54-2532.6-12-09). Concentrations of plasma testosterone and oestradiol were measured by direct radioimmunoassay. 


\section{Sample collection and macrophage cell culture}

Blood for hormone measurement (approx. $2 \mathrm{ml}$ ) was collected into heparinised syringes from the jugular vein, and plasma was separated after centrifugation with $2000 \mathrm{~g}$ at $+4{ }^{\circ} \mathrm{C}$ for $10 \mathrm{~min}$. Blood after decapitation $(10-30 \mathrm{ml})$ was used for white blood cell (WBC) isolation. The spleen was dissected into a Falcon tube with cold phosphate buffered saline (PBS) and subsequently homogenised with a syringe plunger through a sterile sieve. Isolation of macrophages was performed by density gradient centrifugation, using Biocoll Separating Solution (Biochrom AG \# L6115). Briefly, blood or spleen homogenised in PBS was loaded on top of Bicoll solution and centrifuged (12 min, $650 \mathrm{~g}$, room temperature) in order to separate WBC. The obtained WBC were washed with PBS, resuspended in medium (RPMI $+10 \%$ FBS $+1 \%$ penicillin/streptomycin). Cells were checked for viability (10 $\mu 1$ of trypan blue $+10 \mu 1$ of cell suspension), counted and seeded on three 100 $\mathrm{mm}$ dishes for both tissues $\left(10 \mathrm{ml}\right.$ of cell suspension with $2.0 \times 10^{8}$ cells per dish). Dishes were incubated for $48 \mathrm{~h}$ at $40{ }^{\circ} \mathrm{C}$ and $5 \% \mathrm{CO}_{2}$. After two days, macrophages had attached to dishes and cell debris was washed off with sterile PBS. The first dish was stimulated with $10 \mu \mathrm{g} / \mathrm{ml}$ of lipopolysaccharide (LPS; SigmaAldrich, Cat. No. L3012). The second dish was treated with $10 \mu \mathrm{g} / \mathrm{ml}$ LPS + Interferon- $\gamma$; at a dilution of 1:100 with RPMI medium (Weining et al., 1996). The third dish remained untreated as control. Macrophages were further incubated for $24 \mathrm{~h}$ at $40{ }^{\circ} \mathrm{C}$ and $5 \% \mathrm{CO}_{2}$. After incubation, cells were washed with sterile PBS and harvested with a cell scrape, using TriFast solution (PeqLab, Cat. No. 30-2020) to preserve nucleic acids. Samples were incubated for $10 \mathrm{~min}$ at room temperature and subsequently stored at $-20{ }^{\circ} \mathrm{C}$ until mRNA extraction.

\section{Radioimmunoanalysis}

Hormone concentrations were measured by radioimmunoassay (Zeman et al., 1986) without extraction in males and after extraction with a mixture of diethyl ether/petroleum ether in females (Okuliarova et al., 2011). Testosterone was measured using $\left[1,2,6,7-{ }^{3} \mathrm{H}(\mathrm{N})\right]$-testosterone (Perkin Elmer, USA, specific activity $63.47 \mathrm{Ci} / \mathrm{mmoL}$ ) and the specific antibody generated in rabbits against testosterone 3-(O-carboxymethyl)oxime bovine serum albumin (BSA) conjugate (Zeman et al., 1986). Bound and free fractions were separated with dextrancoated charcoal and centrifuged with $3000 \mathrm{~g}$ at $+4{ }^{\circ} \mathrm{C}$ for $10 \mathrm{~min}$. The intra-assay variation coefficients were $10.8 \%$ and $3.8 \%$ for males and females, respectively. The sensitivity of the testosterone assay was $0.60 \mathrm{pg} /$ tube. Oestradiol in plasma extracts was assayed using the same procedure as testosterone. As radiotracer, $\left[2,4,5,7-{ }^{3} \mathrm{H}\right]$-oestradiol (Perkin Elmer, USA, specific activity $72,1 \mathrm{Ci} / \mathrm{mmol}$ ) was used. Specific antibody was generated in rabbits, and its cross-reactivity with all relevant steroids was below $1 \%$. The intra-assay variation coefficient was $4.0 \%$ and the sensitivity of the oestradiol assay was $0.60 \mathrm{pg} /$ tube. 


\section{Molecular analyses}

Isolation of RNA was performed according to the manufacturer's instructions. Concentration and purity of isolated mRNA was evaluated with a NanoDrop spectrophotometer (ND-1000 Spectrophotometer; peqLab Biotechnologie $\mathrm{GmbH}$ ). Integrity of mRNA was evaluated with a Bioanalyzer (Agilent, 2100 Bioanalyzer, G2939A, Serial \#DE54700226), accepting RIN values $>8$ for further analysis. Isolated mRNA was treated with DNase I, RNase free (Fermentas, A5000). Synthesis of cDNA was performed with GoScriptTM Reverse Transcription System (Promega; A5001) according to the manufacturer's instructions (amount of mRNA: $400 \mathrm{ng}$; reaction volume: $20 \mu \mathrm{l}$ ). Prepared cDNA was stored at $-20{ }^{\circ} \mathrm{C}$ before running a PCR.

The analysis of gene expression was performed on a 7300 Real Time PCR System (Applied Biosystems, \#273001422), using SYBR-Green Mastermix (Promega; A6001) with additional reference dye (Promega; C5411). We used the primers listed in Table 1 at a concentration of $300 \mathrm{nM}$. We used mitochondrial ribosomal protein L24 (MRPL24) as a housekeeping gene in this evaluation.

\section{Table 1}

List of primers used in the real-time polymerase chain reaction

\begin{tabular}{|c|c|c|c|}
\hline Gene & Sequence & Primers & $\begin{array}{l}\text { Product } \\
\text { length }\end{array}$ \\
\hline IL-1 & NM_204524 & $\begin{array}{l}\text { F 5'-CTGAGTCATGCATCGTTTATGTTTC-3' } \\
\text { R 5'-AAATACCTCCACCCCGACAAG-3' }\end{array}$ & 120 \\
\hline IL-6 & NM_204628 & $\begin{array}{l}\text { F 5'-GCTTCGACGAGGAGAAATGC-3' } \\
\text { R 5'-GCCAGGTGCTTTGTGCTGTA-3' }\end{array}$ & 139 \\
\hline IL-18 & NM_204608 & $\begin{array}{l}\text { F 5'-TGGAATGCGATGCCTTTTG-3' } \\
\text { R 5'-AAAAGCTGCCACGTTTAAATCTG-3' }\end{array}$ & 104 \\
\hline K60 & NM_205018 & $\begin{array}{l}\text { F 5'-AAAGATGATGGGCAAGGCTGTA-3' } \\
\text { R 5'-GTGCCTGAGCCATACCTTTTG-3' }\end{array}$ & 83 \\
\hline CAF & NM_205498 & $\begin{array}{l}\text { F 5'-CTGGCCCTCCTCCTGGTTTC-3' } \\
\text { R 5'-TGGCGTCAGCTTCACATCTTG-3' }\end{array}$ & 141 \\
\hline K203 & NM_204720 & $\begin{array}{l}\text { F 5'-CCTGCTGCACCACTTACATAACA-3' } \\
\text { R 5'-GCGCTCCTTCTTTGTGATGAA-3' }\end{array}$ & 116 \\
\hline MRPL24 & XM_001232127.3 & $\begin{array}{l}\text { F 5'-TCGATGGCCCCAAAGACA-3' } \\
\text { R 5'-TTAGGGACGGCGTGTAGGTTT-3' }\end{array}$ & 63 \\
\hline
\end{tabular}

The reaction mixture contained $10 \mathrm{ng}$ of cDNA in a total volume of $25 \mu 1$. The reaction was optimised for all primers under real-time PCR conditions given in Table 2. 
Table 2

Programme used for the real-time polymerase chain reaction

\begin{tabular}{lccc}
\hline Phase & Temperature $\left({ }^{\circ} \mathrm{C}\right)$ & Time & Repeat \\
\hline Stage 1 & 95 & $2 \mathrm{~min}$ & $1 \times$ \\
\hline \multirow{2}{*}{ Stage 2 } & 95 & $15 \mathrm{sec}$ & \\
& 59 & $30 \mathrm{sec}$ & $40 \times$ \\
\hline & 72 & $30 \mathrm{sec}$ & \\
Stage 3 & 95 & $15 \mathrm{sec}$ & \\
& 57 & $30 \mathrm{sec}$ & $1 \times$ \\
& 95 & $15 \mathrm{sec}$ & \\
\hline
\end{tabular}

The SDS 2.2.2 programme (Applied Biosystems) was used for evaluating the real-time PCR results in order to get $\mathrm{Ct}$ values. $\Delta \mathrm{Ct}$ values were obtained by normalising reference genes to a housekeeper MRPL24. Afterwards, the control and the LPS-stimulated group were compared to gain $\Delta \Delta \mathrm{Ct}$ values. The formula $2^{\wedge} \Delta \Delta \mathrm{Ct}$ was used for the calculation of gene expression. Results were evaluated by non-parametric statistics (Mann-Whitney test). Age differences in the concentrations of hormones were evaluated by $t$-test for independent samples.

\section{Results}

Plasma steroid hormone concentrations determined in sexually immature and adult birds are shown in Fig. 1. Increased levels of both testosterone and oestradiol were found in adult females as compared to young pullets (testosterone: $\mathrm{t}=-3.639, \mathrm{df}=7, \mathrm{P}<0.01$; oestradiol: $\mathrm{t}=-4.469$, $\mathrm{df}=7, \mathrm{P}<0.01)$. The increase in plasma testosterone levels in males was not significant, due to the high variability found in mature cocks.

The gene expression of proinflammatory cytokines (IL-1 $\beta$, IL-6, IL-18; Fig. 2) and inflammatory chemokines (K60, CAF, K203; Fig. 3) was measured in immune cells isolated either from the blood or from the spleen after in vitro stimulation with LPS. Comparison of the two sexes revealed no significant differences between males and females. Intersexual differences in K203 expression were close to the level of significance $(P=0.08)$ in the group of young chicks. Young males tended to have higher K203 expression in comparison with females (Fig. 3). In adulthood this tendency disappeared.

Clear differences were observed between blood and spleen cells. The most distinct difference was seen in IL-6 gene expression. Monocyte-derived macrophages exhibited significantly higher expression of IL-6 in almost all groups (young females: $\mathrm{P}<0.05$; adult females: $\mathrm{P}=0.127$; young males: $\mathrm{P}<0.05$; adult 
males: $\mathrm{P}<0.05$ ) (Fig. 2). Tissue differences were apparent also in IL-1 $\beta$ expression in young females $(\mathrm{P}<0.05)$ (Fig. 2) and in K203 chemokine expression in young males $(\mathrm{P}<0.05)$ (Fig. 3).
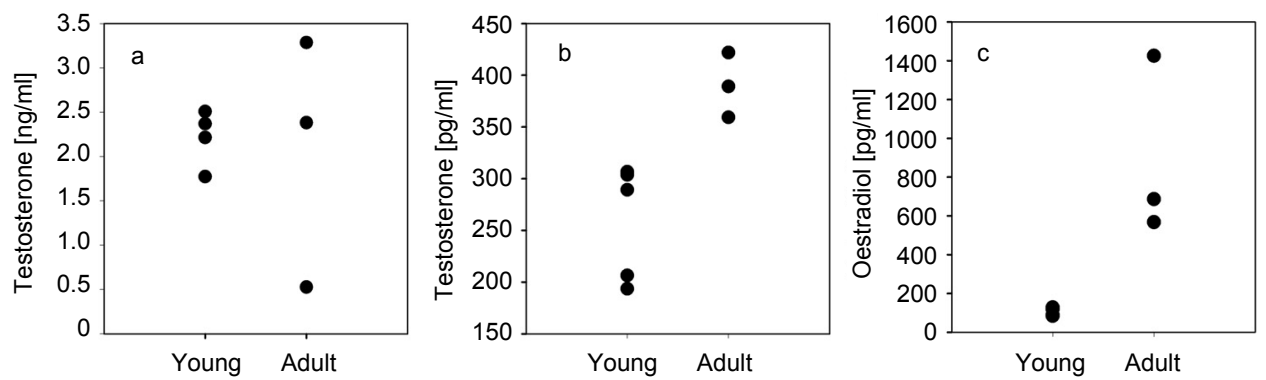

Fig. 1. Plasma testosterone and oestradiol levels in young $(7-11$ weeks old; $n=4)$ and adult (28-29 weeks old; $\mathrm{n}=3$ ) chickens. a: plasma testosterone levels in males; b: plasma testosterone levels in females; c: plasma oestradiol levels in females.

Dots represent exact values. Overlapping values are presented as one dot

\section{Discussion}

In this study, gene expression of proinflammatory cytokines (IL-1 $\beta$, IL-6, IL-18) and inflammatory chemokines (K60, CAF, K203) was measured in chicken mononuclear phagocytic cells after in vitro stimulation with lipopolysaccharide. These genes were selected on the basis of previous studies demonstrating the capability of LPS to stimulate production of proinflammatory cytokines and inflammatory chemokines in vivo (Nakamura et al., 1998; Sijben et al., 2001; Leshchinsky and Klasing, 2003) and in vitro (Fiorentino et al., 1991; Sick et al., 2000).

In this experiment, immune cells from both tissues expressed all the cytokines analysed, although some of them (IL-1 $\beta$, IL-18, CAF) were found to be present at low levels. After LPS stimulation, the strongest induction of gene expression was observed for IL-6 and K203. IL-6 was reported to elicit a febrile response in chicken (Marais et al., 2011) similarly as in mammals (Heinrich et al., 1990). In addition to its involvement in inflammation and innate immunity, IL-6 modulates the activity of cells ensuring acquired immune responses (Diehl et al., 2000; Jones, 2005). Moreover, IL-6 is involved in the stimulation of the hypothalamic-pituitary-adrenal axis, since intravenous administration of purified chicken IL-6 resulted in an increase of circulating corticosterone levels (Schneider et al., 2001). Cytokine K203 belongs to the CC subfamily of chemokines and its gene expression was previously induced by in vitro treatment of chicken cell lines with LPS, chicken IL- $1 \beta$ and IFN- $\gamma$ (Sick et al., 2000). K203 is considered to be an orthologue of human chemokine CCL16 (Hughes et al., 2007). CCL16, 
also called a liver-expressed chemokine, is a powerful stimulator of macrophages. This stimulation leads to an enhanced differentiation of naïve $\mathrm{T}$ cells and a consequent increase in specific cytotoxicity caused by mature $\mathrm{T}$ cells in mice (Cappello et al., 2004). Our results suggest that these two genes are good candidates for use in evaluating the effects of sex steroid hormones on the immune system in birds.

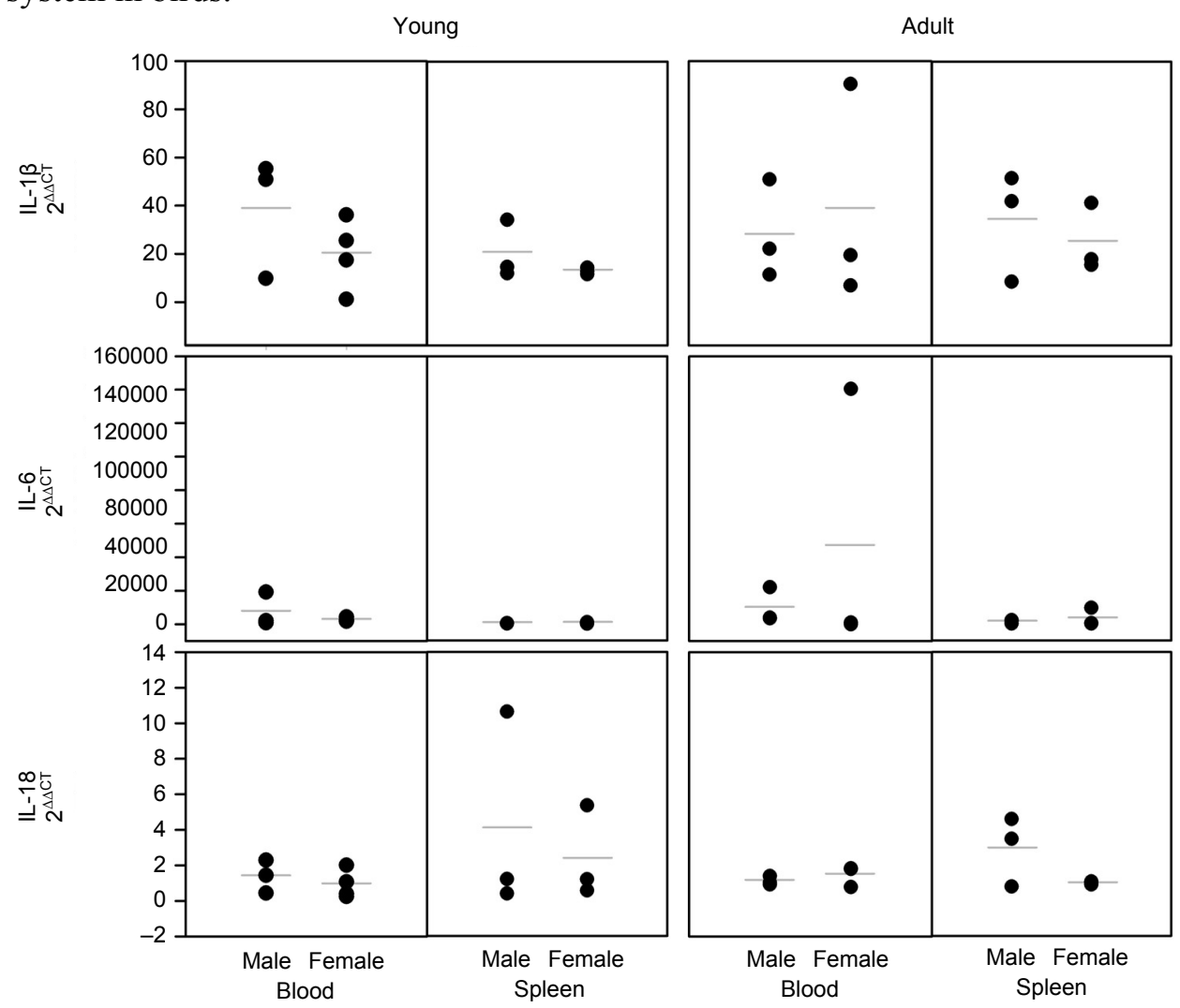

Fig. 2. Gene expression $\left(2^{\Delta \Delta \mathrm{CT}}\right)$ of chosen cytokines in monocytes derived from blood and spleen of young (7-11 weeks old) and adult (28-29 weeks old) chickens. Dots represent exact values and grey lines express their mean. Young males: $n=3$; young females: $n=4$; adult males: $n=3$; adult females: $\mathrm{n}=3$. Overlapping values are presented as one dot. IL-1 $\beta$ : interleukin $1 \beta$;

IL-6: interleukin 6; IL-18: interleukin 18

In addition to a cluster of immunologically active substances, we also analysed the responses of different subpopulations of phagocytic mononuclear cells and measured cytokines produced either by mononuclear cells derived from the blood (monocytes) or the spleen (macrophages). It is possible that our cell culture contained also other cells, such as dendritic cells (Quéré et al., 2013) or thrombocytes (Scott and Owens, 2008), which may have also contributed to the 
overall mRNA pool. Nevertheless, blood-derived monocytes responded to LPS stimulation by a higher increase in the gene expression of proinflammatory cytokines and chemokines (especially IL-6, IL-1 $\beta$ and K203) than did spleen macrophages (Figs 2 and 3). Although these two subpopulations belong to one population of phagocytic cells, they are localised in different environments with specific regulatory signals. Monocytes circulate in the bloodstream and react to proinflammatory, metabolic and immune stimuli. Afterwards, they penetrate through the vascular endothelium into tissues, where they specialise according to the local environment (Van Furth et al., 1972). Resident macrophages show a high level of specialisation (Gordon and Taylor, 2005) as indicated by their localisation in different spleen compartments. There are several different groups of these cells which perform various functions from the recognition and clearance of blood-borne pathogens (van der Laan et al., 1999) to the production of cytokines (den Haan and Kraal, 2012). Blood monocytes are fully functional cells of the immune system but not so narrowly specialised, and they might respond more strongly to stimulation with LPS than tissue macrophages. Therefore, they seem to be good candidates for the identification of intersexual differences. However, we did not phenotype the isolated cells, so we cannot be completely sure that our adherent cell culture contained solely mononuclear cells.

Our results indicate a tendency $(\mathrm{P}=0.08)$ to intersexual differences in the gene expression of chemokine K203 in the group of young birds (Fig. 3). Other cytokines and chemokines did not differ significantly between the two sex or age groups. Intersexual differences in cytokine gene expression were previously described in mice. Differences in basal gene expression of IFN- $\gamma$ and IL-4 were observed under in vivo conditions. These data were also supported by in vitro experiments proving significant effects of female gonadal hormones (but not testosterone) on the gene expression levels of these cytokines in splenocytes. On the other hand, the same study found no evidence for an effect of sex on gene expression levels of IL-2 or IL-6 (De León-Nava et al., 2009). Other in vitro studies revealed stimulation of the gene expression of IL-2, IL-3 and IL-5 by both female and male gonadal steroids in human T-cell lines (Wang et al., 1993). In murine splenic macrophages, 17 $\beta$-oestradiol down-regulates the LPS-induced production of IL- $1 \alpha$, IL- 6 and TNF- $\alpha$. However, the gene expression of IL-10, IL-12, and macrophage inflammatory protein was not affected (Deshpande et al., 1997). In our pilot study we validated real-time PCR for the quantification of immune cell response after LPS stimulation. We quantified relative mRNA levels of several different cytokines and chemokines which were previously demonstrated to play a role in the immune response in chickens (Kaiser et al., 2006; Swaggerty et al., 2008; Kogut et al., 2013). The evaluation of gene expression alone does not automatically prove that also the active protein is present. However, the available literature suggests that this method is very sensitive and higher mRNA expression is associated with the resistance of animals to various 
pathogens (Wigley et al., 2006; Kogut et al., 2013). Because of the higher number of analysed genes we included only a small number of experimental animals. Therefore, the non-significant differences found between the groups might result from the low number of animals and the high variability of immunological parameters.

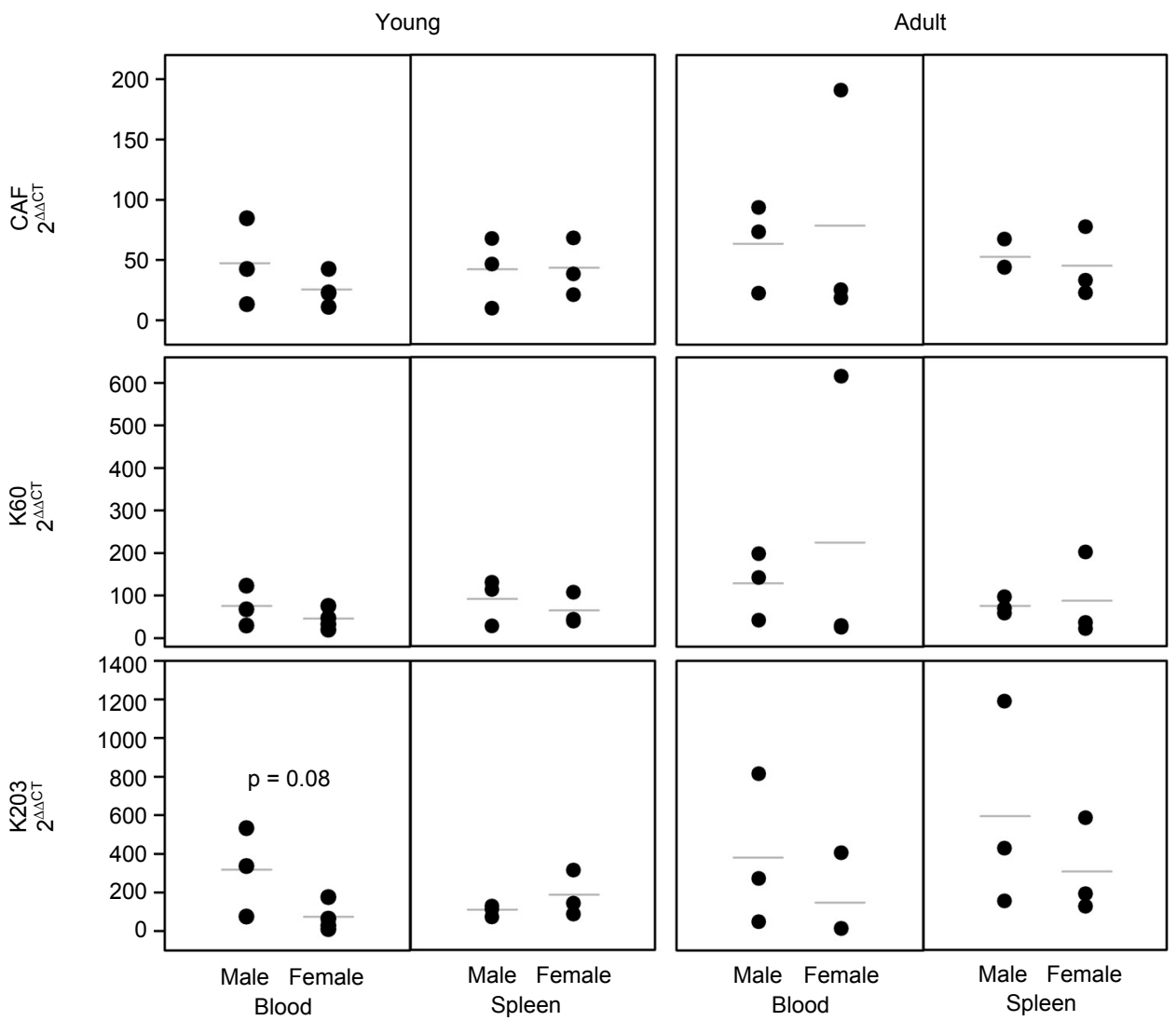

Fig. 3. Gene expression $\left(2^{\Delta \Delta \mathrm{CT}}\right)$ of chosen chemokines in monocytes derived from blood and spleen of young (7-11 weeks old) and adult (28-29 weeks old) chickens. Dots represent exact values and red lines express their mean. Young males: $\mathrm{n}=3$; young females: $\mathrm{n}=4$; adult males: $\mathrm{n}=3$; adult females: $n=3$. Overlapping values are presented as one dot. CAF: interleukin-8 like chicken chemokine (CXCLi2); K60: interleukin-8 like chicken chemokine (CXCLi1); K203: chicken chemokine of CC family

In conclusion, mononuclear phagocytic cells isolated from blood and spleen responded to in vitro LPS stimulation by the increased gene expression of proinflammatory mediators (especially IL-6 and K203). Generally, the effect of stimulation was more pronounced in monocytes than in spleen macrophages. We found a trend to intersexual differences in the gene expression of chemokine 
K203. Our study provides the first insight into avian intersexual and agedependent differences in the gene expression of cytokines and chemokines. The findings represent a basis for further investigations into the effect of sex hormones on immune phenotypes of birds, and more data are needed for identifying the key molecules and processes.

\section{References}

Beagley, K. W. and Gockel, C. M. (2003): Regulation of innate and adaptive immunity by the female sex hormones oestradiol and progesterone. FEMS Immunol. Med. Microbiol. 38, 13-22.

Cappello, P., Caorsi, C., Bosticardo, M., De Angelis, S., Novelli, F., Forni, G. and Giovarelli, M. (2004): CCL16/LEC powerfully triggers effector and antigen-presenting functions of macrophages and enhances T cell cytotoxicity. J. Leukocyte Biol. 75, 135-142.

De León-Nava, M. A., Nava, K., Soldevila, G., López-Griego, L., Chávez-Ríos, J. R., VargasVillavicencio, J. A. and Morales-Montor, J. (2009): Immune sexual dimorphism: effect of gonadal steroids on the expression of cytokines, sex steroid receptors, and lymphocyte proliferation. J. Steroid Biochem. Mol. Biol. 113, 57-64.

den Haan, J. M. and Kraal, G. (2012): Innate immune functions of macrophage subpopulations in the spleen. J. Innate Immun. 4, 437-445.

Deshpande, R., Khalili, H., Pergolizzi, R. G., Michael, S. D. and Chang, M.-D., Y. (1997): Estradiol down-regulates LPS-induced cytokine production and NFkB activation in murine macrophages. Am. J. Reprod. Immunol. 38, 46-54.

Diehl, S., Anguita, J., Hoffmeyer, A., Zapton, T., Ihle, J. N., Fikrig, E. and Rincón, M. (2000): Inhibition of Th1 differentiation by IL-6 is mediated by SOCS1. Immunity 13, 805-815.

Fiorentino, D. F., Zlotnik, A., Mosmann, T., Howard, M. and O'Garra, A. (1991): IL-10 inhibits cytokine production by activated macrophages. J. Immunol. 147, 3815-3822.

Gilliver, S. C. (2010): Sex steroids as inflammatory regulators. J. Steroid Biochem. Mol. Biol. 120, $105-115$.

Gordon, S. and Taylor, P. R. (2005): Monocyte and macrophage heterogeneity. Nat. Rev. Immunol. 5, 953-964.

Hartmann, W. (1988): Evaluation of 'major genes' affecting disease resistance in poultry in respect to their potential for commercial breeding. Prog. Clin. Biol. Res. 307, 221-231.

Heinrich, P. C., Castell, J. V. and Andus, T. (1990): Interleukin-6 and the acute phase response. Biochem. J. 265, 621.

Hughes, S., Poh, T.-Y., Bumstead, N. and Kaiser, P. (2007): Re-evaluation of the chicken MIP family of chemokines and their receptors suggests that CCL5 is the prototypic MIP family chemokine, and that different species have developed different repertoires of both the CC chemokines and their receptors. Dev. Comp. Immunol. 31, 72-86.

Jones, S. A. (2005): Directing transition from innate to acquired immunity: defining a role for IL-6. J. Immunol. 175, 3463-3468.

Kaiser, M., Cheeseman, J., Kaiser, P. and Lamont, S. (2006): Cytokine expression in chicken peripheral blood mononuclear cells after in vitro exposure to Salmonella enterica serovar Enteritidis. Poult. Sci. 85, 1907-1911.

Khan, K. N., Masuzaki, H., Fujishita, A., Kitajima, M., Sekine, I., Matsuyama, T. and Ishimaru, T. (2005): Estrogen and progesterone receptor expression in macrophages and regulation of hepatocyte growth factor by ovarian steroids in women with endometriosis. Hum. Reprod. 20, 2004-2013.

Kogut, M. H., Genovese, K. J., He, H., Swaggerty, C. L. and Jiang, Y. (2013): Modulation of chicken intestinal immune gene expression by small cationic peptides as feed additives during the first week posthatch. Clin. Vaccine Immunol. 20, 1440-1448. 
Landsman, T., Leitner, G., Robinzon, T. and Helle, E. (2001): Effect of gonadal steroids on proliferative responses and subset alterations in cultured chicken lymphocytes. Poult. Sci. 80, $1329-1338$.

Leshchinsky, T. and Klasing, K. (2003): Profile of chicken cytokines induced by lipopolysaccharide is modulated by dietary alpha-tocopheryl acetate. Poult. Sci. 82, 1266-1273.

Marais, M., Maloney, S. K. and Gray, D. A. (2011): Brain IL-6-and PG-dependent actions of IL-1 $\beta$ and lipopolysaccharide in avian fever. Am. J. Physiol. Regul. Integr. Comp. Physiol. 301, R791-R800.

Murphy, A. J., Guyre, P. M., Wira, C. R. and Pioli, P. A. (2009): Estradiol regulates expression of estrogen receptor ERa46 in human macrophages. PLoS ONE 4, e5539.

Nakamura, K., Mitarai, Y., Yoshioka, M., Koizumi, N., Shibahara, T. and Nakajima, Y. (1998): Serum levels of interleukin-6, alpha ${ }_{1}$-acid glycoprotein, and corticosterone in two-weekold chickens inoculated with Escherichia coli lipopolysaccharide. Poult. Sci. 77, 908-911.

Okuliarova, M., Groothuis, T. G., Škrobánek, P. and Zeman, M. (2011): Experimental evidence for genetic heritability of maternal hormone transfer to offspring. Am. Nat. 177, 824-834.

Quéré, P., Pierre, J., Hoang, M.-D., Esnault, E., Domenech, J., Sibille, P. and Dimier-Poisson, I. (2013): Presence of dendritic cells in chicken spleen cell preparations and their functional interaction with the parasite Toxoplasma gondii. Vet. Immunol. Immunopathol. 153, 57-69.

Schneider, K., Klaas, R., Kaspers, B. and Staeheli, P. (2001): Chicken interleukin-6. Eur. J. Biochem. 268, 4200-4206.

Scott, T. and Owens, M. D. (2008): Thrombocytes respond to lipopolysaccharide through Toll-like receptor-4, and MAP kinase and NF- $\mathrm{BB}$ pathways leading to expression of interleukin-6 and cyclooxygenase-2 with production of prostaglandin E2. Mol. Immunol. 45, 1001-1008.

Sick, C., Schneider, K., Staeheli, P. and Weining, K. C. (2000): Novel chicken CXC and CC chemokines. Cytokine 12, 181-186.

Sijben, J., Schrama, J., Parmentier, H., Van der Poel, J. and Klasing, K. (2001): Effects of dietary polyunsaturated fatty acids on in vivo splenic cytokine mRNA expression in layer chicks immunized with Salmonella typhimurium lipopolysaccharide. Poult. Sci. 80, 1164-1170.

Swaggerty, C. L., Pevzner, I. Y., Kaiser, P. and Kogut, M. H. (2008): Profiling pro-inflammatory cytokine and chemokine mRNA expression levels as a novel method for selection of increased innate immune responsiveness. Vet. Immunol. Immunopathol. 126, 35-42.

van der Laan, L. J., Döpp, E. A., Haworth, R., Pikkarainen, T., Kangas, M., Elomaa, O., Dijkstra, C. D., Gordon, S., Tryggvason, K. and Kraal, G. (1999): Regulation and functional involvement of macrophage scavenger receptor MARCO in clearance of bacteria in vivo. J. Immunol. 162, 939-947.

Van Furth, R., Cohn, Z., Hirsch, J., Humphrey, J., Spector, W. and Langevoort, H. (1972): The mononuclear phagocyte system: a new classification of macrophages, monocytes, and their precursor cells. Bull. World Health Organ. 46, 845.

Wang, Y., Campbell, H. and Young, I. (1993): Sex hormones and dexamethasone modulate interleukin-5 gene expression in T lymphocytes. J. Steroid Biochem. Mol. Biol. 44, 203-210.

Weining, K. C., Schultz, U., Minster, U., Kaspers, B. and Staeheli, P. (1996): Biological properties of recombinant chicken interferon- $\gamma$. Eur. J. Immunol. 26, 2440-2447.

Whitacre, C. C. (2001): Sex differences in autoimmune disease. Nat. Immunol. 2, 777-780.

Wigley, P., Hulme, S., Rothwell, L., Bumstead, N., Kaiser, P. and Barrow, P. (2006): Macrophages isolated from chickens genetically resistant or susceptible to systemic salmonellosis show magnitudinal and temporal differential expression of cytokines and chemokines following Salmonella enterica challenge. Infect. Immun. 74, 1425-1430.

Wunderlich, F., Benten, W. P. M., Lieberherr, M., Guo, Z., Stamm, O., Wrehlke, C., Sekeris, C. E. and Mossmann, H. (2002): Testosterone signaling in T cells and macrophages. Steroids 67, $535-538$.

Zeman, M., Kosutzky, J. and Bobakova, E. (1986): Testosterone concentration in the seminal plasma of cocks. Br. Poult. Sci. 27, 261-266. 